\title{
KEPRIBADIAN GURU DAPAT MEMPENGARUHI KINERJA GURU DI SEKOLAH DASAR NEGERI CIRACAS 03
}

\author{
Mirna Herawati \\ Dosen Program Studi Pendidikan Ekonomi Universitas Indraprasta PGRI \\ E-mail : mirnathar19@gmail.com
}

\begin{abstract}
Abstrak
Tujuan penelitian adalah untuk mengetahui pengaruh kepribadian Guru terhadap kinerja Guru di Sekolah Dasar Negeri Ciracas 03. Metode penelitian yang digunakan dalam penelitian ini adalah metode kuantitatif. Sumber data yang digunakan adalah Guru di Sekolah Dasar Negeri Ciracas 03 dengan responden sebanyak 30 Guru. Teknik dalam pengumpulan data yang digunakan dalam penelitian ini adalah menggunakan kuisioner (angket). Dari hasil perhitungan nilai korelasi product moment sebesar $\mathrm{r}=$ 0,849 berada dalam skala yang sangat kuat dan perhitungan koefisien determinasi yang hanya memberikan kontribusi kepribadian terhadap kinerja Guru hanya sebesar 72,10\%. Kemudian hasil dari pengujian hipotesis menunjukkan nilai $-\mathrm{t}_{\text {hitung }}<-\mathrm{t}_{\text {tabel }}$ atau $-6,370<-0,367$ sehingga disimpulkan bahwa terdapat pengaruh yang sangat signifikan kepribadian terhadap kinerja Guru di Sekolah Dasar Negeri Ciracas 03.
\end{abstract}

Kata kunci : kepribadian Guru, kinerja Guru

\section{PENDAHULUAN}

Penjaminan mutu pendidikan nasional dipengaruhi oleh kinerja para pengelola, penyelenggara, dan pelaku pendidikan dari tingkat sekolah sampai ketingkat pusat. Komponen-komponen pendidikan yang mampu mendukung keberhasilan penjaminan mutu pendidikan adalah: organisasi dan manajemen, sumber daya manusia, fasilitas, program, dan kegiatan serta partisipasi masyarakat.

Dalam proses belajar mengajar, guru menempati posisi penting dan penentu berhasil tidaknya pencapaian tujuan suatu proses pembelajaran. Sekalipun proses pembelajaran telah menggunakan berbagai model pendekatan dan metode yang lebih memberi peluang siswa aktif, kedudukan dan peran guru tetap penting dan menentukan.

Guru dihadapkan dengan harapan masyarakat yang terlalu 'perfeksionis' dan berlebihan. Dalam kondisi seperti yang tidak menentu, masyarakat tetap menuntut agar guru selalu memiliki idealisme sebagai figur pengajar dan pendidik yang bersih dari cacat hukum dan moral. Beban guru ini semakin menjadi berat ketika para siswa sekarang ini semakin masa bodoh terhadap persoalan-persoalan moral, mereka terjebak dalam sikap yang serba instan. Akibatnya guru merasa kehilangan cara yang terbaik dan tidak punya nilai edukatif dalam menanggapi perilaku pelajar. 
Menghadapi tantangan dan beban tugas yang sangat berat tersebut, seorang guru diharapkan untuk lebih meningkatkan profesionalismenya, sehingga ia tidak gagap ketika mengemban misinya sebagai penyemai intelektual, pemupuk nilai kemanusiaan,dan penyubur nilai moral kepada murid-murid.

Lemahnya nilai profesional calon guru bisa nenurun karena sejak awal mahasiswa tidak sungguh-sungguh menguasai materi dan intelegensinya rendah, kedua calon guru tidak siap dengan metode pengajaran, dan yang terakhir motivasi menjadi penddidik makin rendah.

Walaupun calon guru dikatakan kurang profesional, tetapi sekarang calon-calon guru tersebut sudah menjadi guru atau pendidik yang tersebar di sekolah-sekolah formal. Jika demikian yang terjadi, maka anak-anak yang merupakan murid mereka tidak menerima pembelajaran yang bermutu, padahal peserta didik adalah anak manusia yang memiliki potensi fisik mental yang unik, sedang berkembang, butuh bimbingan dan perlakuan manusiawi, mampu mandiri, memiliki hak, tanggung jawab, dan kewajiban dalam belajar. Mereka mempunyai hak untuk mendapatkan pendidikan formal yang baik. Sebagai manusia muda, anak-anak perlu membekali dirinya dengan ilmu pengetahuan yang mendukung sampai saat mereka dewasa nanti. Kemudian mereka wajib dan mempertanggung jawabkan hasil proses belajar dalam kehidupan masyarakat dan bernegara.

Sebagai Guru sudah seyogyanya mengetahui tentang seluk beluk guru, untuk menjadi seorang guru dituntut untuk memiliki setidaknya empat kompetensi, salah satunya adalah kepribadian guru, pada penelitian ini akan membahas tentang seperti apa seharusnya kepribadian seorang Guru.

Berdasarkan hal diatas maka peneliti tertarik ingin meneliti tentang “Kepribadian dapat Mempengaruhi Kinerja Guru di Sekolah Dasar Negeri Ciracas 03".

Adapun dari tujuan penelitian ini adalah untuk mengetahui kepribadian Guru terhadap kinerja Guru di Sekolah Dasar Negeri Ciracas 03.

\section{TINJAUAN PUSTAKA}

\section{Kinerja Guru}

Kinerja adalah sebuah kata dalam bahasa Indonesia dari kata dasar "kerja" yang menterjemahkan kata dari bahasa asing prestasi. Bisa pula berarti hasil kerja. 
Pengertian Kinerja dalam organisasi merupakan jawaban dari berhasil atau tidaknya tujuan organisasi yang telah ditetapkan. Para atasan atau manajer sering tidak memperhatikan kecuali sudah amat buruk atau segala sesuatu jadi serba salah. Terlalu sering manajer tidak mengetahui betapa buruknya kinerja telah merosot sehingga perusahaan/instansi menghadapi krisis yang serius. Kesan-kesan buruk organisasi yang mendalam berakibat dan mengabaikan tanda - tanda peringatan adanya kinerja yang merosot.

Malayu S.P. Hasibuan (2003:34) mengemukakan "kinerja (prestasi kerja) adalah suatu hasil kerja yang dicapai seseorang dalam melaksanakan tugas yang dibebankan kepadanya yang didasarkan atas kecakapan, pengalaman dan kesungguhan serta waktu".

Kinerja yaitu suatu kegiatan atau aktivitas yang berhubungan erat dengan tiga aspek pokok yaitu perilaku, hasil dan efektivitas organisasi. Perilaku menunjukkan suatu kegiatan untuk mencapai tujuan, efektivitas merupakan langkah-langkah dalam pertimbangan hasil kerja, organisasional menekankan pada aspek proses kerja.

Berhubungan dengan kinerjanya maka guru memiliki kinerja yang baik ada yang memiliki kinerja yang kurang baik. Guru yang memiliki kinerja baik sering disebut guru yang profesional sedangkan pengertian kinerja dalam Kamus Besar Bahasa Indonesia bahwa kinerja itu sesuatu yang diraih atau dicapai, prestasi yang diperhatikan, kemampuan kerja.

\section{Kinerja Guru sebagai Performansi dalam pembelajaran.}

Guru yang memiliki kinerja yang baik dan profesional memiliki beberapa kemampuan antara lain : (1) Guru harus memiliki ketrampilan untuk mendiagnosis siswanya dalam hal kemampuan, perhatian dan kepribadian, (2) Guru harus mengetahui bahwa guru itu bekerja dengan siswa, (3) Guru harus mengetahui berbagai metode yang efektif untuk membuat setiap siswa mencapai prestasi yang optimal, (4) Guru harus memiliki pemahaman yang luas terhadap tujuan pendidikan.

Menurut Richey (1973:95) Guru yang profesional memiliki kualitas mengajar yang tinggi, ada lima variabel yang menandai kualitas mengajar yang tinggi yaitu membuat perencanaan dan persiapan mengajar, menggunakan alat peraga dalam mengajar dan mengikutsertakan dalam berbagai pengalaman baru yang tinggi yakni:

1. Bekerja dengan siswa secara individu, meliputi (1) memberi tugas secara 
individual, (2) pekerjaan peserta didik segera diperiksa dan segera dikembalikan, (3) hubungan antara guru dan siswa sangat akrab, (4) percakapan antara guru dan siswa sering dilakukan untuk menolong siswa.

2. Perencanaan dan persiapan mengajar, meliputi (1) membuat perencanaan dan strategi belajar, (2) mengadakan praktek lapangan,

3. pengetahuan guru adalah merupakan sumber belajar dan ditambah buku penunjang lainnya, materi pelejaran yang esensial selalu disajikan.

4. Penggunaan alat peraga meliputi (1) guru memberi tugas dan ketrampilan yang berhubungan dengan alat-alat praktek mengajar, (2) guru selalu memanfaatkan buku pelajaran, (3) guru memberi tugas yang terkait dengan buku perpustakaan.

5. Mengikutsertakan siswa dalam berbagai pengalaman belajar, meliputi : (1) guru memberi tanggungjawabnya kepada siswa dalam tugas-tugasnya. (2) guru mengikutsertakan siswanya dalam menyususn rencana pembelajaran, (3) guru menyajikan bermacam-macam pengalaman belajar, (4) guru memberi motivasi belajar kepada peserta didik.

6. Kepemimpinan aktif guru meliputi (1) membantu peserta didik dalam memecahkan masalah, (2) memberi kesempatan kepada peserta didik untuk menjadi pemimpin, (3) mendayagunakan permainan sebagai media belajar (4) memberi kesempatan kepada siswa untuk berdiskusi dan mengemukakan pendapatnya.

Menurut Gordon dan Burch (1997:381) guru yang profesional atau guru yang mempunyai kinerja yang tinggi adalah guru yang efektif dalam menjalin hubungan dengan peserta didik sehingga terjadi saling pengertian, saling percaya antara kedua belah pihak. Lebih lanjut Gordon mengemukakan bahwa guru yang efektif adalah guru yang memiliki ciri-ciri sebagai berikut : (a) lebih mengutamakan pesan saya daripada pesan anda, (b) memilih metode menang-menangan dalam menyelesaikan konflik, (c) selalu menggunakan bahasa penerimaan dan menghindari bahasa penolakan (d) berdoa dan pasrah kepada Allah SWT bila semua usaha yang ditempuh namun permasalahan tetap belum selesai.

\section{Kinerja Guru sebagai Prestasi dalam Pembelajaran.}

Standar prestasi kerja guru adalah minimal yang wajib dilaksanakan guru dalam proses pembelajaran dan bimbingan. Standar Prestasi Kerja Guru tersebut meliputi : 
1. Penyusunan Program Pembelajaran terdiri dari:
a. Analisis Materi Pelajaran (AMP)
b. Program Tahunan (Prota)
c. Program Semester (Promes)
d. Program Satuan Pembelajaran (PSP)
e. Rencana Pembelajaran (RP)
f. Alat evaluasi (AE)
g. Program Perbaikan dan pengayaan
h. Program Bimbingan Konseling

2. Pelaksanaan Program Pembelajaran, meliputi :
a. Pelaksanaan pembelajaran di kelas
b. Penggunaan strategi pembelajaran
c. Penggunaan media dan sumber belajar

3. Pelaksanaan Evaluasi, meliputi :
a. Evaluasi hasil belajar
b. Evaluasi pencapaian target kurikulum
c. Evaluasi daya serap.

4. Analisis evaluasi, meliputi :
a. Analisis ketuntasan belajar
b. Analisis butir soal

5. Pelaksanaan Perbaikan dan Pengayaan, meliputi :

a. Pelaksanaan perbaikan pembelajaran

b. Pelaksanaan pengayaan pembelajaran.

Berdasarkan beberapa teori yang sudah dikemukakan dapatlah disimpulkan bahwa kinerja guru akan dapat ditingkatkan dengan melakukan perencanaan program pembelajaran yang sesuai dengan program yang direncanakan, diadakan evaluasi pembelajaran dan pelaksanaan perbaikan dan pengayaan pembelajaran itu.

\section{Tipe Kepribadian Guru}

Menurut asal katanya, kepribadian atau personality berasal dari bahasa Latin personare, yang berarti mengeluarkan suara (to sound through). Istilah ini digunakan untuk menunjukkan suara dari percakapan seorang pemain sandiwara melalui topeng (masker) yang dipakainya. Pada mulanya istilah persona berarti topeng 
yang dipakai oleh pemain sandiwara, di mana suara pemain sandiwara itu diproyeksikan. Kemudian kata persona itu berarti pemain sandiwara itu sendiri (Ngalim Purwanto, 2004: 154).

Istilah personality terutama menunjukkan suatu organisasi/susunan daripada sifat-sifat dan aspek-aspek tingkah laku lainnya yang saling berhubungan di dalam suatu individu. Sifat-sifat dan aspek-aspek ini bersifat psikofisik yang menyebabkan individu berbuat dan bertindak seperti apa yang dia lakukan, dan menunjukkan adanya ciri-ciri khas yang membedakan individu itu dengan individu yang lain. Termasuk di dalamnya: sikapnya, kepercayaannya, nilai-nilai dan cita-citanya, pengetahuan dan keterampilannya, macam-macam cara gerak tubuhnya, dan sebagainya (Ngalim Purwanto, 2004: 154).

Kepribadian menurut Robbins (2002: 84) menyatakan bahwa "Kepribadian sering didefinisikan sebagai gabungan dari semua cara dimana individu bereaksi dan berinteraksi dengan orang-orang lain".

Menurut Luthans (2006: 62) kepribadian adalah “ organisasi internal dari proses psikologis dan kecenderungan perilaku seseorang".

Jadi kepribadian itu merupakan perangkat gambaran diri yang terintegrasi dan merupakan perangkat total dari kekuatan intrapsikis, yang membuat diri kita ini menjadi unik, dengan perilaku yang spesifik.

Definisi kepribadian menurut Nugroho J. Setiadi (2003:130) menyatakan bahwa

"Kepribadian adalah organisasi yang dinamis dari system psikofisis individu yang menentukan penyesuaian dirinya terhadap lingkungannya secara unik". Kepribadian seorang dewasa umumnya sekarang dianggap terbuat dari baik factor keturunan maupun lingkungan, yang diperlunak oleh faktor situasi”.

Definisi kepribadian menurut Aqib Zainal (2002: 120) menyatakan bahwa "Kepribadian adalah organisasi dinamik dari system-sistem psikologis dalam individu yang menentukan penyesuainnya yang unik terhadap lingkungannya”.

Jadi kepribadian itu merupakan perangkat gambaran diri yang terintegrasi dan merupakan perangkat total dari kekuatan intrapsikis, yang membuat diri kita ini menjadi unik, dengan perilaku yang spesifik.

Keturunan merujuk ke faktor-faktor yang ditentukan pada saat pembuahan. Sosok fisik, daya tarik wajah, kelamin, temperamen, komposisi otot dan reflek, tingkat 
energi, dan ritme hayati merupakan karakteristik-karakteristik yang dianggap sebagai atau sama sekali atau sebagian besar dipengaruhi oleh kedua orang tua. Pendekatan keturunan berargumen bahwa penjelasan paling akhir dari kepribadian seorang individu adalah struktur molekul dari gen-gen yang terletak dalam kromosom.

Diantara faktor-faktor yang menggunakan tekanan pada pembentukan kepribadian kita adalah budaya dalam mana kita dibesarkan, pengkondisian dini kita, norma-norma diantara keluarga kita, teman-teman, dan kelompok-kelompok social, serta pengaruh-pengaruh lain yang kita alami. Lingkungan yang dipaparkan memainkan peranan yang cukup besar dalam membentuk kepribadian.

Situasi mempengaruhi efek keturunan dan lingkungan pada kepribadian. Kepribadian seorang individu, sementara umumnya mantap dan konsisten, memang berubah dalam situasi yang berbeda.

Kepribadian biasanya dijelaskan dengan menggunakan ciri-ciri seperti kepercayaan diri, dominasi, otonomi, ketaatan, kemampuan bersosialisasi, daya tahan dan kemampuan beradaptasi.

Identifikasi enam belas sifat kepribadian utama (introvert dan ekstrovert), yaitu:

Tabel 1. Enam Belas Sifat Kepribadian Utama

\begin{tabular}{lcl}
\hline Introvert & & Ekstrovert \\
\hline Penyendiri & vs & Peramah \\
\hline Kecerdasan rendah & vs & Kecerdasan tinggi \\
\hline Dipengaruhi oleh perasaan & vs & Stabil secara emosional \\
\hline Pengikut & & \\
\hline Serius & vs & Dominan \\
\hline Berani mengambil risiko & vs & Santai \\
\hline Pemalu & & \\
\hline Keras hati & vs & Petualang \\
\hline Mudah Percaya & vs & Peka \\
\hline Praktis & vs & Pencuriga \\
\hline Blak-blakan & vs & Imajinatif \\
\hline Percaya diri & vs & Tersembunyi pertimbangan \\
\hline Konservatif & vs & Mudah cemas \\
\hline Tergantung Kelompok & vs & Suka mencoba \\
\hline Tidak Terkendali & vs & Mandiri \\
\hline Rileks & vs & Terkendali \\
\hline
\end{tabular}

Masa ini adalah masa dimana orang-orang berkepribadian ekstrovert disanjungsanjung dan berkepribadian ekstrovert itu sendiri dianggap baik. Mereka yang 
ekstrovert dipandang sebagai orang-orang yang mampu bersosialisasi dengan baik, luwes, fleksibel dan memiliki kepribadian yang menawan. Sementara mereka yang introvert dipandang buruk, canggung, dan tidak memiliki kemampuan bersosialisasi.

Orang-orang introvert adalah mereka yang terampil dalam melakukan perjalanan kedunia dalam, yaitu diri mereka sendiri, mereka selalu mencoba memahami diri mereka sendiri dengan melakukan banyak perenungan dan berkontemplasi. Pada akhirnya mereka menjadi orang yang memahami dirinya, berpendirian keras, tidak mudah terpengaruh oleh orang lain, dan mengetahui apa yang menjadi tujuan dalam hidupnya.

Namun mereka yang introvert seringkali terlalu disibukkan dengan dirinya sendiri, kurang peka terhadap lingkungannya dan akhirnya lingkungannya juga tidak dapat menerima mereka yang introvert dengan baik. Mereka tahu apa yang mereka mau namun sulit untuk mengkomunikasikannya kepada orang lain. Hal ini membuat mereka yang introvert seringkali dicap sebagai orang aneh.

Sementara itu mereka yang ekstrovert terampil dalam melakukan perjalanan kedunia luar. Mereka dengan luwes dapat berinteraksi dengan banyak orang. Membuat orang lain terkagum-kagum dan menyukainya. Namun semua ini dilakukan dengan mengorbankan dirinya sendiri.

Seseorang dapat menjadi ekstrovert atau introvert, tergantung dengan arah aktivitas mereka. Ekstrovert adalah orang yang berpikir mengenai hal-hal secara objektif dan luas, sedangkan introvert lebih berpikir kearah subjektif atau dirinya sendiri.

Ekstrovert: (a) tertarik dengan apa yang terjadi disekitar mereka, (b) terbuka dan seringkali banyak bicara, (c) membandingkan pendapat mereka dengan pendapat orang lain, (d) seperti aksi dan inisiatif, (e) mudah mendapat teman atau beradaptasi dalam grup baru, (f) mengatakan apa yang mereka pikirkan, (g) tertarik dengan orang-orang baru, (h) mudah menolak bersahabat dengan orang-orang yang tidak diinginkan.

Introvert: (a) tertarik dengan pikiran dan perasaannya sendiri, (b) memerlukan teritori mereka sendiri, (c) tampil dengan muka pendiam dan tampak penuh pemikiran, (d) biasanya tidak mempunyai banyak teman, (e) sulit membuat hubungan baru, (f) menyukai konsentrasi dan kesunyiaan, (g) tidak suka dengan kunjungan yang tidak diharapkan dan tidak suka mengunjungi orang lain, (h) bekerja dengan baik sendirian. 


\section{Hubungan Kepribadian Guru dengan Kinerja Guru}

Kepribadian adalah organisasi yang dinamis dari sistem psikofisis individu yang menentukan penyesuaian dirinya terhadap lingkungannya secara unik. Kepribadian seorang dewasa umumnya terbentuk dari faktor keturunan maupun lingkungan, yang diperlunak oleh faktor situasi. Kepribadian ekstrovert tersebut, antara lain: (peramah, kecerdasan tinggi, stabil secara emosional, dominant, santai, bijaksana/penuh pertimbangan, petualang, peka, pencuriga, imajinatif, tersembunyi, mudah cemas, suka mencoba, mandiri, terkendali, tegang). Kepribadian introvert tersebut, antara lain: (penyendiri, kecerdasan rendah, dipengaruhi oleh perasaan, pengikut, serius, berani mengambil resiko, pemalu, keras hati, mudah percaya, praktis, blak-blakan, percaya diri, konservatif, tergantung kelompok, tidak terkendali, rileks).

Faktor yang mempengaruhi tipe kepribadian adalah: (a) adaptasi (suka bergaul, dan banyak bicara), (b) Keramahtamahan (baik hati, kooperatif, dan dapat dipercaya), (c) Kehati-hatian (bertanggung jawab, dapat diandalkan, tekun, dan berorientasi pada prestasi), (d) Kestabilan emosional (tenang, antusias, dan sanggup (positif) menghadapi ketegangan, kegelisahan, kemurungan, dan ketidakamanan (negatif), (e) Keterbukaan terhadap pengalaman (imajinatif, dan cerdas).

Kinerja adalah hasil kerja (prestasi kerja) yang dicapai seseorang dalam melaksanakan tugasnya, sehingga akan menunjukkan bahwa orang yang bersangkutan memiliki kualitas atau kompetensi dibidangnya.

Kinerja guru adalah prestasi yang dapat dicapai seseorang atau organisasi bedasarkan criteria dan alat ukur tetentu. Kinerja guru merupakan hasil yang dapat dicapai dalam melaksanakan tugas-tugas yang dibebankan kepadanya berdasarkan kecakapan, pengalaman, dan kesungguhan serta waktu yang tersedia. Wujud dari kinerja guru direalisasikan oleh kompetensi, yaitu (1) pedagogic adalah kemampuan mengolah pembelajaran peserta didik, (2) kepribadian adalah kemampuan kepribadian yang mantap, berakhlak mulia, arif, dan berwibawa serta menjadi teladan peserta didik, (3) professional adalah kemampuan penguasaan materi pelajaran secara luas dan mendalam, dan (4) social adalah kemampuan guru untuk berkomunikasi dan berinteraksi secara efektif dan efisien dengan peserta didik, sesama guru, orang tua/wali peserta didik, dan masyarakat sekitar. 
Kinerja guru merupakan prestasi atau pencapaian hasil kerja yang dicapai guru berdasarkan standar dan ukuran penilian yang ditetapkan. Standar dan alat ukur tersebut merupakan indicator untuk menentukan apakah seorang guru berkinerja tinggi atau rendah.

Faktor yang mempengaruhi kinerja adalah: (a) kemampuan (penguasaan materi dan penguasaan metode mengajar), (b) inisiatif (mewujudkan kreatifitas dan pencapaian prestasi), (c) ketepatan waktu (pemanfaatan waktu kedatangan dan pemanfaatan waktu pulang), (d) kualitas hasil kerja (kepuasaan siswa, pemahaman siswa, dan prestasi siswa), (e) komunikasi (mutu penyampaian materi dan penguasaan kelas).

Dari uraian tersebut, maka tipe kepribadian guru yang baik akan mempengaruhi kinerja guru. Seorang guru yang memiliki kepribadian yang baik akan berusaha meningkatkan kinerjanya agar mencapai tujuan yang telah direncanakan.

\section{METODE}

Metode penelitian merupakan cara yang digunakan oleh peneliti dalam mengumpulkan data. Metode dalam penelitian ini adalah metode penelitian kuantitatif. Metode penelitian kuantitatif adalah metode yang lebih menekankan pada aspek pengukuran secara obyektif terhadap fenomena sosial. Untuk dapat melakukan pengukuran, setiap fenomena sosial dijabarkan kedalam beberapa komponen masalah, variabel dan indikator. Setiap variabel yang ditentukan di ukur dengan memberikan simbol - simbol angka yang berbeda - beda sesuai dengan kategori informasi yang berkaitan dengan variabel tersebut. Dengan menggunakan simbol - simbol angka tersebut, teknik perhitungan secara kuantitatif matematik dapat dilakukan sehingga dapat menghasilkan suatu kesimpulan yang belaku umum di dalam suatu parameter. Tujuan utama dari metodologi ini ialah menjelaskan suatu masalah tetapi menghasilkan generalisasi. Generalisasi ialah suatu kenyataan kebenaran yang terjadi dalam suatu realitas tentang suatu masalah yang di perkirakan akan berlaku pada suatu populasi tertentu. Generalisasi dapat dihasilkan melalui suatu metode perkiraan atau metode estimasi yang umum berlaku didalam statistika induktif. Metode estimasi itu sendiri dilakukan berdasarkan pengukuran terhadap keadaan nyata yang lebih terbatas lingkupnya yang juga sering disebut "sampel" dalam penelitian kuantitatif. Jadi, yang 
diukur dalam penelitian sebenarnya ialah bagian kecil dari populasi atau sering disebut "data". Data ialah contoh nyata dari kenyataan yang dapat diprediksikan ke tingkat realitas dengan menggunakan metodologi kuantitatif tertentu. Penelitian kuantitatif mengadakan eksplorasi lebih lanjut serta menemukan fakta dan menguji teori-teori yang timbul.

\section{HASIL DAN PEMBAHASAN}

\section{Menentukan Harga $\mathbf{t}_{\text {hitung }}$}

Uji hipotesis yang telah dirumuskan diuji tingkat signifikannya dengan uji $t$ menggunakan rumus sebagai berikut :

$\mathrm{t}_{\text {hitung }}=\frac{r \sqrt{n-2}}{\sqrt{1-r^{2}}}$

Tabel 2. Coefficients

\begin{tabular}{|c|c|c|c|c|c|}
\hline \multirow[t]{2}{*}{ Model } & \multicolumn{2}{|c|}{ Unstandardized Coefficients } & \multirow{2}{*}{$\begin{array}{c}\begin{array}{c}\text { Standardized } \\
\text { Coefficients }\end{array} \\
\text { Beta }\end{array}$} & \multirow[t]{2}{*}{$\mathrm{t}$} & \multirow[t]{2}{*}{ Sig. } \\
\hline & B & Std. Error & & & \\
\hline (Constant) & $-231,286$ & 36,306 & & $-6,370$ & ,000 \\
\hline kepribadian & 2,222 & ,237 & ,849 & 9,374 &, 000 \\
\hline
\end{tabular}

a. Dependent Variable: kinerja

Perhitungan t hitung menggunakan SPSS Versi 2.1 seperti yang tertera pada tabel 1.1 yaitu $t_{\text {hitung }}$ sebesar $-6,370$

\section{Menentukan Harga $t_{\text {tabel }}$}

$\mathrm{t}_{\text {tabel }}$ yang dicari pada $\alpha=5 \%$ uji dua pihak dengan $\mathrm{dk}=\mathrm{n}-1$. Nilai $\mathrm{t}_{\text {tabel }}$ pada $\alpha=$ $5 \%$ uji dua pihak dengan $\mathrm{df}=\mathrm{n}-1$ adalah $-0,367$.

\section{Simpulan}

Kriteria $-\mathrm{t}$ hitung $<\mathrm{t}$ tabel atau $-6,370<-0,367$ maka Ho berada di daerah penolakan pada $\alpha=0,05$. Dengan demikian kepribadian Guru mempunyai pengaruh terhadap kinerja Guru. 
Research and Development Journal Of Education

Vol. 4 No. 2 April 2018

ISSN 2406-9744

\section{UCAPAN TERIMA KASIH}

Dengan ini penulis mengucapkan rasa syukur kepada Allah SWT tang telah memberikan rahmat dan hidayah-Nya, serta penulis mengucapkan terimakasih kepada Sekolah Dasar Negeri Negeri Ciracas 03, serta ucapan terimakasih kepada semua pihak yang telah membantu.

\section{DAFTAR PUSTAKA}

Gordon T \& Burch, N. 1997. Teacher Effectivenes for Training, Terjemahan oleh Adhitya Kumara Dewi. Jakarta: PT Gramedia Pustaka Utama.

Hasibuan M. 2003. Manajemen Sumber Daya Manusia. Yogjakarta: BPFE.

Luthans Fred. 2006. Perilaku Organisasi. Yogyakarta: Andi.

Ngalim, Purwanto. 2004. Psikologi Pendidikan. Bandung: Remaja Rosdakarya.

Richey, R.W. 1973. Planning for Teaching and Introduction, Fourth Edition. Colorado: Mc Graw-Hill.

Robbins P. Stephen. 2002. Prinsip-prinsip Perilaku Organisasi. Jakarta: Erlangga.

Setiadi J. Nugroho. 2003. Perilaku Konsumen. Jakarta: Kencana.

Zainal, Aqib. 2002. Profesionalisme Guru dalam Pembelajaran. Surabaya: Insan 